\title{
Optimization of Cassava (Manihot esculenta Crantz)- Wheat (Triticum aestivum) Bread with Alpha-amylase and Xylanase
}

Ronalyn B. Veril ${ }^{1 *}$ and Felix J. Amestoso ${ }^{2}$

\section{ABSTRACT}

The combination action of a-amylase, xylanase, and composite flour was analyzed to determine their effects on the sensory quality of bread through optimization using Central Composite Design (CCD) of the Response Surface Methodology. Fifteen bread formulations containing different concentrations of a-amylase $(0,0.0005$, and $0.003 \% \mathrm{w} / \mathrm{w})$, xylanase $(0,0.001$ and $0.003 \% \mathrm{w} / \mathrm{w})$, and composite flour $(15,30,45 \% \mathrm{w} / \mathrm{w})$ were used in the experiment. The study revealed that a-amylase significantly influenced the response of crust color, crumb structure, flavor, and general acceptability of the bread. The presence of xylanase caused a change in the response of crust color, crumb texture, and the general acceptability only. However, its cross product interaction with composite flour level affected the response of crust color, crumb texture and structure, flavor, and the overall acceptability of the product. The synergistic effect of a-amylase and xylanase displayed a positive effect on the overall acceptability of the bread. The optimum formulation set at acceptability rating of $\geq 7.20$ on the 9-point Hedonic scale was determined at $38 \%$ composite flour with $0.002 \%$ a-amylase and $0.0012 \%$ xylanase with a cost of P41.14 per $421.27 \mathrm{~g}$ of loaf. The observed acceptability mean for all sensory attributes of the formulation was not significantly different from the predicted acceptability mean value of the model according to the verification test. This formulation was not significantly different from the commercial bread available in the local market of Baybay City, Leyte based on the consumer acceptance results with children and adults as potential target market.

Keywords: a-amylase, xylanase, cassava flour, composite bread, sensory evaluation

${ }^{1}$ Bohol Island State University - Candijay Campus, Candijay, Bohol, Philippines

${ }^{2}$ Visayas State University, Department of Food Science and Technology, Visca, Baybay City, Leyte, Philippines 


\section{INTRODUCTION}

The backbone ingredient of bread is flour, and in general, wheat flour is the most commonly used in the baking industry due to its protein composition that results in good quality bread. Nevertheless, flour characteristics vary due to wheat variety, season availability, production cost, and milling technology. Although millers attempt to blend wheat from different sources to produce flour with good and consistent baking quality, it often proves difficult to satisfy both high-quality and low-cost standards at the same time (Whitehurst \& Oort 2009). Moreover, because bread preferences differ, the baking industry uses ingredients with different qualities and employs different baking procedures.

Nowadays, consumer preferences are shifting towards healthier products. It is possible to make new bread varieties by simply adjusting the formulation or baking procedure. However, in other cases, bakers may have to develop new techniques. Therefore, both millers and bakers need ingredients or process aids such as chemical oxidants, emulsifiers, and enzymes to standardize the quality of the products and diversify the product range (Miguel et al 2013).

Baked goods, such as breads, have close links with enzymes. Alphaamylase and xylanase are among the enzymes used in bread making (Butt et al., 2006). Due to the changes in the baking industry and the ever increasing demand for more natural products, enzymes have gained increasing importance because they improve dough and bread quality leading to improved dough flexibility, machinability, stability, loaf volume, and crumb structure (Baillet et al 2003).

The production of bread using composite flour containing different levels of cassava and wheat flour with the incorporation of enzymes aamylase and xylanase, which are considered dough improvers, was explored in this study.

\section{MATERIALS AND METHODS}

\section{Procurement of Materials}

Commercial flour from cassava and wheat, white sugar, refined salt, dry yeast, lard, vanilla, and other baking ingredients were procured at the local market in Baybay City. Commercial enzyme powder (a-amylase and xylanase) was purchased online from Advanced Enzyme Technologies Ltd.

\section{Preparation of Composite Flour}

The composite flour used was a mixture of commercial wheat flour and cassava flour. The amounts of cassava flour added were 15, 30, and 45 (\% 
$\mathrm{w} / \mathrm{w}$ ) based on 100 gram total flour mixture. The levels used were based on the flour substitution level conducted by Eriksson (2013) which were $10 \%$ to $20 \%$ using different varieties of cassava in the absence of any dough improver. The ingredients were prepared and mixed according to standard procedure. The composite flour without enzymes served as the control bread sample. The flours were packed in polyethylene bags and stored in a dry place.

\section{Experimental Design}

The optimum formulation of cassava-wheat bread was identified using the $3^{3}$ fractional factorial design, Central Composite Design (CCD) as presented in Figure 1, through Statistica version 9 software. The independent variables were: composite flour combination, amount of aamylase $(0 \%, 0.0005 \%$, and $0.003 \%)$, and amount of xylanase $(0 \%, 0.001 \%$, and $0.003 \%) \% \mathrm{w} / \mathrm{w}$ based on quantity of flour used. The amount of enzymes considered was based on the product dosage recommended by the manufacturer of the product. Processing of the different loaf samples with different combinations of cassava-wheat flour followed 15 treatments presented in Table 1 based on Figure 1. For comparison, one treatment was processed containing $0 \%$ enzymes, $0 \%$ cassava flour, and $100 \%$ wheat flour.

Table 1. Experimental combinations of a-amylase, xylanase, and cassavawheat flour used for optimization of the cassava-wheat bread formulation

\begin{tabular}{cccc}
\hline & \multicolumn{3}{c}{ Variables } \\
\cline { 2 - 4 } Treatments & $\begin{array}{c}\text { a-amylase } \\
\text { Level } \\
(\% \text { w/w) }\end{array}$ & $\begin{array}{c}\text { Level of xylanase } \\
(\% \text { w/w) }\end{array}$ & $\begin{array}{c}\text { Composite flour Level } \\
\text { (\% w/w cassava:wheat) }\end{array}$ \\
\hline $\mathrm{T}_{1}$ & 0.003 & 0.000 & $15: 85$ \\
$\mathrm{~T}_{2}$ & 0.003 & 0.000 & $45: 55$ \\
$\mathrm{~T}_{3}$ & 0.003 & 0.003 & $45: 55$ \\
$\mathrm{~T}_{4}$ & 0.003 & 0.003 & $15: 85$ \\
$\mathrm{~T}_{5}$ & 0.000 & 0.000 & $15: 85$ \\
$\mathrm{~T}_{6}$ & 0.000 & 0.000 & $45: 55$ \\
$\mathrm{~T}_{7}$ & 0.000 & 0.003 & $45: 55$ \\
$\mathrm{~T}_{8}$ & 0.000 & 0.003 & $15: 85$ \\
$\mathrm{~T}_{9}$ & 0.0005 & 0.000 & $30: 70$ \\
$\mathrm{~T}_{10}$ & 0.0005 & 0.001 & $45: 55$ \\
$\mathrm{~T}_{11}$ & 0.0005 & 0.003 & $30: 70$ \\
$\mathrm{~T}_{12}$ & 0.0005 & 0.001 & $15: 85$ \\
$\mathrm{~T}_{13}$ & 0.003 & 0.001 & $30: 70$ \\
$\mathrm{~T}_{14}$ & 0.000 & 0.001 & $30: 70$ \\
$\mathrm{~T}_{15}$ & 0.0005 & 0.001 & $30: 70$ \\
\hline
\end{tabular}




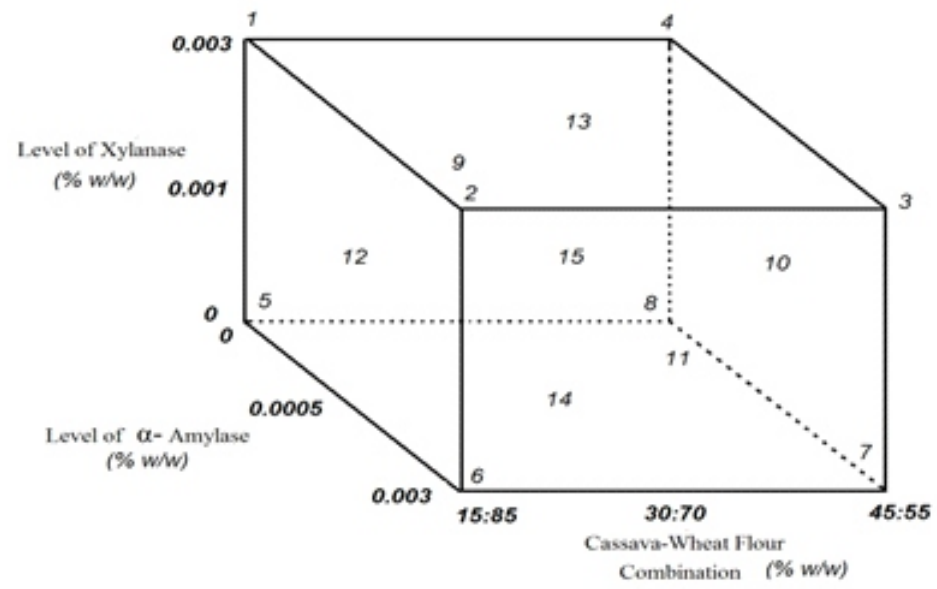

Figure 1. Central Composite Design for the optimization of cassava-wheat bread

\section{Baking Process}

The amount of white sugar, yeast, dough improver, eggs, vanilla, salt, lard, and water were held constant in the formulation of the 15 treatments. Bread dough was prepared by manually mixing all the baking ingredients for 1 minute, then kneading it in the machine until it was well developed. The dough was then fermented in a bowl covered with a clean cloth for 55 minutes at room temperature. After the first fermentation, the dough was further proofed after being placed in a pan for 5 hours at $28^{\circ} \mathrm{C}$, and baked at $250^{\circ} \mathrm{C}$ for 20 minutes.

\section{Sensory Evaluation}

Sensory evaluation of the product's color, aroma, taste, texture, and general acceptability was carried out using the 9-point Hedonic scale. The presentation of samples to the panelists followed the Incomplete Block Design (IBD), as laid out by Cochran and Cox (1957), using set plan $t=15, k=3$, $r=7, b=35, \lambda=1, E=0.71$, Type I where $\underline{t}$ refers to the number of treatments, $r$ the number of replications based on the IBD, $\underline{b}$ the number of blocks, and $E$ the efficiency factor.

The evaluation was done in two replications to minimize error. Samples presented to each panelist were coded using three digit numbers similar to the codes indicated on their score sheet.

\section{Statistical Analysis}

Data obtained in the sensory evaluation was analyzed using the Statistical Analytical Software version 9 (SAS, 2008). The graphical presentation of the responses using surface and contour plots were obtained using the STATISTICA 8.0 software. Verification result was analyzed through Analysis of Variance (ANOVA) and t-test. 


\section{Production Cost Determination}

The calculation of the total production cost for each treatment of cassava-wheat bread was based on the prevailing market price of all the raw materials used as well as other overhead cost. The product cost was compared to the current price of existing products.

\section{Verification Test}

Another sensory evaluation was conducted to verify the sensory acceptability of the optimum formulation. The result provided the model equation's predictive ability. The evaluation considered 32 panelists and $t-$ test was used to compare the predicted and observed values of the product.

\section{RESULTS AND DISCUSSION}

\section{Sensory Evaluation for Optimization Experiment}

Table 2 summarizes the F-ratio values from the Analysis of Variance (ANOVA) for all the sensory attributes of cassava-wheat bread. The parameter estimates of the product using response surface regression are shown in Table 3, while Table 4 presents the acceptability mean of every attribute of the bread. Table 5 indicates the summary description of each treatment of cassava-wheat bread.

Table 2. Summary of F-ratio values from Analysis of Variance (ANOVA) for the different sensory attributes of cassava-wheat bread

\begin{tabular}{|c|c|c|c|c|c|c|c|c|}
\hline Regression & $\begin{array}{l}\text { Crust } \\
\text { Color }\end{array}$ & $\begin{array}{l}\text { Crumb } \\
\text { Color }\end{array}$ & $\begin{array}{l}\text { Crumb } \\
\text { Texture }\end{array}$ & $\begin{array}{c}\text { Crumb } \\
\text { Structure }\end{array}$ & Aroma & Taste & Flavor & GA \\
\hline Linear & $3.68^{*}$ & $1.15^{\mathrm{ns}}$ & $2.11^{\mathrm{ns}}$ & $1.92^{\mathrm{ns}}$ & $0.32^{\mathrm{ns}}$ & $1.00^{\mathrm{ns}}$ & $0.38^{\mathrm{ns}}$ & $3.90^{\text {** }}$ \\
\hline Quadratic & $1.35^{\mathrm{ns}}$ & $1.19^{\mathrm{ns}}$ & $2.91^{*}$ & $2.78^{*}$ & $1.72^{\mathrm{ns}}$ & $1.24^{\mathrm{ns}}$ & $4.76^{* *}$ & $4.54^{* *}$ \\
\hline $\begin{array}{l}\text { Cross - } \\
\text { Product }\end{array}$ & $2.07^{\mathrm{ns}}$ & $1.33^{\mathrm{ns}}$ & $3.34^{*}$ & $4.20^{\star *}$ & $0.32^{\mathrm{ns}}$ & $0.09^{\mathrm{ns}}$ & $5.24^{\star \star}$ & $3.42^{*}$ \\
\hline Total Model & $2.37^{*}$ & $1.22^{\mathrm{ns}}$ & $2.79^{* *}$ & $2.97^{* *}$ & $0.79^{\mathrm{ns}}$ & $0.78^{\mathrm{ns}}$ & $3.46^{\star \star *}$ & $3.96^{* \star *}$ \\
\hline
\end{tabular}

Table 3. Summary of parameter estimates for the response surface of the sensory acceptability of all the sensory attributes of cassava-wheat bread

\begin{tabular}{|c|c|c|c|c|c|c|c|c|}
\hline Parameter & $\begin{array}{l}\text { Crust } \\
\text { Color }\end{array}$ & $\begin{array}{l}\text { Crumb } \\
\text { Color }\end{array}$ & $\begin{array}{l}\text { Crumb } \\
\text { Texture }\end{array}$ & $\begin{array}{c}\text { Crumb } \\
\text { Structure }\end{array}$ & Aroma & Taste & Flavor & GA \\
\hline Intercept & $7.38^{\text {whx }}$ & $7.59^{\text {stx }}$ & $7.47^{* 2 \pi}$ & $7.65^{\text {tax }}$ & $7.39^{\text {stx }}$ & $7.27^{\text {the }}$ & $7.74^{\text {the }}$ & $7.73^{\text {whx }}$ \\
\hline Amylase & $0.51^{\star \star}$ & $0.15^{\mathrm{ns}}$ & $0.16^{\text {ns }}$ & $0.15^{\text {ns }}$ & $0.05^{\mathrm{ns}}$ & $0.18^{\mathrm{ns}}$ & $0.32^{\star}$ & $0.45^{\star \star}$ \\
\hline Xylanase & $-0.14^{\mathrm{ns}}$ & $-0.18^{\mathrm{ns}}$ & $-0.20^{\mathrm{ns}}$ & $-0.18^{\mathrm{ns}}$ & $0.04^{\mathrm{ns}}$ & $-0.12^{\text {ns }}$ & $0.01^{\mathrm{ns}}$ & $-0.20^{\mathrm{ns}}$ \\
\hline $\begin{array}{l}\text { CF } \\
\text { Amy*Amy }\end{array}$ & $\begin{array}{l}0.08^{\mathrm{ns}} \\
0.45^{\mathrm{ns}}\end{array}$ & $\begin{array}{l}0.06^{\mathrm{ns}} \\
0.19^{\mathrm{ns}}\end{array}$ & $\begin{array}{l}-0.22^{\text {ns }} \\
-0.02^{\text {ns }}\end{array}$ & & $\begin{array}{l}-0.13^{\text {ns }} \\
-0.06^{\text {ns }}\end{array}$ & $\begin{array}{l}-0.30^{\text {ns }} \\
-0.48^{\text {ns }}\end{array}$ & $\begin{array}{c}0.06^{\mathrm{ns}} \\
-0.97^{\mathrm{ns}}\end{array}$ & $\begin{array}{l}-0.18^{\text {ns }} \\
-0.70^{\text {ns }}\end{array}$ \\
\hline Xyl* Amy & $-0.11^{\mathrm{ns}}$ & $-0.04^{\mathrm{ns}}$ & $0.24^{\mathrm{ns}}$ & $0.13^{\text {ns }}$ & $-0.12^{\mathrm{ns}}$ & $-0.11^{\mathrm{ns}}$ & $0.07^{\mathrm{ns}}$ & $0.34^{\star}$ \\
\hline
\end{tabular}


Table 3. Continuation

\begin{tabular}{|c|c|c|c|c|c|c|c|c|}
\hline Parameter & $\begin{array}{l}\text { Crust } \\
\text { Color }\end{array}$ & $\begin{array}{l}\text { Crumb } \\
\text { Color }\end{array}$ & $\begin{array}{l}\text { Crumb } \\
\text { Texture }\end{array}$ & $\begin{array}{c}\text { Crumb } \\
\text { Structure }\end{array}$ & Aroma & Taste & Flavor & GA \\
\hline Xyl*Xyl & $-0.81^{\star}$ & $-0.58^{\mathrm{nS}}$ & $-0.79 *$ & $-0.34^{\mathrm{ns}}$ & $-0.66^{*}$ & $-0.77^{\mathrm{ns}}$ & $-0.37^{n S}$ & $-0.75^{\star}$ \\
\hline CF*Amy & $0.19^{\mathrm{ns}}$ & $0.30^{\mathrm{ns}}$ & $0.13^{\mathrm{ns}}$ & $0.27^{\mathrm{ns}}$ & $0.02^{\mathrm{ns}}$ & $-0.01^{\mathrm{ns}}$ & $0.24^{\mathrm{ns}}$ & $0.19^{\mathrm{ns}}$ \\
\hline$C F^{*} \times y \mid$ & $0.43^{*}$ & $-0.09^{\text {ns }}$ & $0.51^{\star \star *}$ & $0.64^{* * *}$ & $-0.09^{n s}$ & $0.03^{\mathrm{ns}}$ & $0.65^{\star \star \star}$ & $0.33^{*}$ \\
\hline$C F * C F$ & $0.19^{\mathrm{ns}}$ & $0.00^{\mathrm{ns}}$ & $-0.32^{\mathrm{ns}}$ & $-0.11^{\mathrm{ns}}$ & $0.38^{\mathrm{ns}}$ & $0.30^{\mathrm{ns}}$ & $-0.56^{\mathrm{ns}}$ & $-0.16^{\mathrm{ns}}$ \\
\hline
\end{tabular}

${ }^{*}$ - significant at $\mathrm{P}<0.05 \quad{ }^{* *} \quad$ - significant at $\mathrm{P}<0.01{ }^{* * *} \quad$ - significant at $\mathrm{P}<0.001 \quad$ ns - not significant $\mathrm{GA}$ - general acceptability

Table 4. Mean ${ }^{1}$ acceptability ratings ${ }^{2}$ for all sensory attributes of cassava-wheat bread as affected by varying levels of a-amylase, xylanase, and composite flour

\begin{tabular}{|c|c|c|c|c|c|c|c|c|c|c|c|}
\hline \multirow[b]{2}{*}{ TRT } & \multirow[b]{2}{*}{ A } & \multirow[b]{2}{*}{ B } & \multirow[b]{2}{*}{ C } & \multicolumn{8}{|c|}{ Sensory Characteristics' Acceptability Rating } \\
\hline & & & & $\begin{array}{l}\text { Crust } \\
\text { Color }\end{array}$ & $\begin{array}{c}\text { Crumb } \\
\text { Color }\end{array}$ & $\begin{array}{l}\text { Crumb } \\
\text { Texture }\end{array}$ & $\begin{array}{l}\text { Crumb } \\
\text { Structure }\end{array}$ & Aroma & Taste & Flavor & GA \\
\hline 1 & 0.003 & 0 & $15: 85$ & 7.71 & 7.36 & 7.14 & 7.00 & 7.36 & 7.00 & 7.00 & 7.07 \\
\hline 2 & 0.003 & 0 & $45: 55$ & 7.93 & 7.79 & 6.86 & 6.79 & 7.36 & 6.86 & 6.79 & 7.07 \\
\hline 3 & 0.003 & 0.003 & $45: 55$ & 7.64 & 7.50 & 7.14 & 6.93 & 7.14 & 6.43 & 7.43 & 7.21 \\
\hline 4 & 0.003 & 0.003 & $15: 85$ & 7.36 & 7.21 & 6.93 & 6.71 & 7.36 & 7.00 & 6.57 & 7.21 \\
\hline 5 & 0 & 0 & $15: 85$ & 7.43 & 7.50 & 7.36 & 7.64 & 7.07 & 7.21 & 7.00 & 7.50 \\
\hline 6 & 0 & 0 & $45: 55$ & 6.36 & 7.36 & 6.57 & 6.00 & 7.00 & 6.36 & 6.21 & 6.43 \\
\hline 7 & 0 & 0.003 & $45: 55$ & 7.29 & 7.07 & 6.93 & 6.79 & 7.14 & 6.57 & 6.93 & 6.57 \\
\hline 8 & 0 & 0.003 & $15: 85$ & 6.64 & 7.43 & 6.36 & 6.29 & 7.36 & 6.71 & 6.29 & 6.29 \\
\hline 9 & 0.0005 & 0 & $30: 70$ & 7.00 & 7.29 & 7.29 & 7.21 & 7.00 & 6.71 & 7.43 & 7.29 \\
\hline 10 & 0.0005 & 0.001 & $45: 55$ & 7.43 & 7.50 & 6.71 & 6.93 & 7.43 & 7.43 & 6.93 & 7.21 \\
\hline 11 & 0.0005 & 0.003 & $30: 70$ & 6.86 & 7.21 & 6.71 & 6.93 & 7.07 & 6.93 & 7.21 & 6.86 \\
\hline 12 & 0.0005 & 0.001 & $15: 85$ & 7.36 & 7.57 & 7.79 & 7.50 & 7.57 & 7.21 & 7.50 & 7.57 \\
\hline 13 & 0.003 & 0.001 & $30: 70$ & 7.43 & 7.79 & 7.36 & 6.93 & 7.14 & 7.36 & 7.43 & 7.57 \\
\hline 14 & 0 & 0.001 & $30: 70$ & 7.79 & 7.50 & 7.50 & 6.93 & 7.50 & 6.86 & 7.21 & 7.21 \\
\hline 15 & 0.0005 & 0.001 & $30: 70$ & 7.21 & 7.71 & 7.50 & 7.57 & 7.29 & 6.64 & 7.07 & 7.36 \\
\hline $\begin{array}{c}\text { Overall } \\
\text { Mean }\end{array}$ & & & & 7.30 & 7.45 & 7.08 & 6.94 & 7.25 & 6.89 & 7.00 & 7.10 \\
\hline
\end{tabular}

${ }^{1} \mathrm{~N}=14$ A- a-Amylase Level (\% w/w) $\quad$ B- Xylanase Level (\% w/w) C- Composite Flour Level (\% w/w) TRT - Treatment GA- General Acceptability

${ }^{2}$ Range of scores (9-point Hedonic scale):

9- like extremely

8- like very much

7- like moderately

6- like slightly

5- neither like nor dislike

4- dislike slightly

3- dislike moderately

2- dislike very much

1- dislike extremely 
Table 5. Summary of the quality descriptions for all the sensory attributes of cassava-wheat bread with enzymes

\begin{tabular}{|c|c|c|c|c|c|c|c|}
\hline \multirow[b]{2}{*}{ TRT } & \multicolumn{7}{|c|}{ Sensory Characteristics' Description } \\
\hline & $\begin{array}{l}\text { Crust } \\
\text { Color }\end{array}$ & $\begin{array}{l}\text { Crumb } \\
\text { Color }\end{array}$ & $\begin{array}{c}\text { Crumb } \\
\text { Texture }\end{array}$ & $\begin{array}{c}\text { Crumb } \\
\text { Structure }\end{array}$ & Aroma & Taste & Flavor \\
\hline 1 & $\begin{array}{l}\text { deep } \\
\text { golden } \\
\text { brown }\end{array}$ & white & $\begin{array}{c}\text { slightly } \\
\text { spongy \& } \\
\text { soft }\end{array}$ & $\begin{array}{l}\text { slightly } \\
\text { porous }\end{array}$ & $\begin{array}{c}\text { moderately } \\
\text { perceptible } \\
\text { toasted smell }\end{array}$ & $\begin{array}{c}\text { slightly to } \\
\text { moderately } \\
\text { sweet }\end{array}$ & $\begin{array}{c}\text { Well- } \\
\text { blended } \\
\mathrm{C}_{1} \& \mathrm{~W} \\
\end{array}$ \\
\hline 2 & $\begin{array}{l}\text { light } \\
\text { golden } \\
\text { brown }\end{array}$ & $\begin{array}{l}\text { creamy } \\
\text { white }\end{array}$ & $\begin{array}{c}\text { slightly } \\
\text { spongy \& } \\
\text { soft }\end{array}$ & $\begin{array}{c}\text { slightly to } \\
\text { moderately } \\
\text { porous }\end{array}$ & $\begin{array}{c}\text { moderately } \\
\text { perceptible } \\
\text { toasted smell }\end{array}$ & $\begin{array}{l}\text { slightly } \\
\text { sweet }\end{array}$ & $\begin{array}{l}\text { more } \mathrm{W} \\
\text { than } \mathrm{C}_{1}\end{array}$ \\
\hline 3 & $\begin{array}{l}\text { golden } \\
\text { brown }\end{array}$ & white & $\begin{array}{l}\text { slightly to } \\
\text { moderately } \\
\text { spongy \& } \\
\text { soft }\end{array}$ & $\begin{array}{c}\text { very small } \\
\text { aerated } \\
\text { pores/intact }\end{array}$ & $\begin{array}{c}\text { slightly } \\
\text { perceptible } \\
\text { toasted smell }\end{array}$ & $\begin{array}{l}\text { slightly } \\
\text { sweet }\end{array}$ & $\begin{array}{c}\text { well } \\
\text { blended } \\
\mathrm{C}_{1} \& \mathrm{~W}\end{array}$ \\
\hline 4 & $\begin{array}{l}\text { light } \\
\text { golden } \\
\text { brown }\end{array}$ & pale white & $\begin{array}{l}\text { moderately } \\
\text { spongy } \\
\& \text { soft }\end{array}$ & $\begin{array}{l}\text { slightly } \\
\text { porous }\end{array}$ & $\begin{array}{c}\text { slightly to } \\
\text { moderately } \\
\text { perceptible } \\
\text { toasted smell }\end{array}$ & $\begin{array}{l}\text { slightly } \\
\text { sweet }\end{array}$ & $\begin{array}{c}\text { well } \\
\text { blended } \\
\mathrm{C}_{1} \& \mathrm{~W}\end{array}$ \\
\hline 5 & $\begin{array}{l}\text { golden } \\
\text { brown }\end{array}$ & pale white & $\begin{array}{l}\text { slightly to } \\
\text { moderately } \\
\text { spongy \& } \\
\text { soft }\end{array}$ & $\begin{array}{c}\text { slightly to } \\
\text { very small } \\
\text { aerated } \\
\text { pores }\end{array}$ & $\begin{array}{c}\text { slightly } \\
\text { perceptible } \\
\text { toasted smell }\end{array}$ & $\begin{array}{l}\text { slightly } \\
\text { sweet }\end{array}$ & $\begin{array}{c}\text { well } \\
\text { blended } \\
\mathrm{C}_{1} \& \mathrm{~W}\end{array}$ \\
\hline 6 & $\begin{array}{l}\text { light } \\
\text { golden } \\
\text { brown }\end{array}$ & pale white & $\begin{array}{l}\text { slightly } \\
\text { spongy \& } \\
\text { soft }\end{array}$ & $\begin{array}{l}\text { slightly } \\
\text { porous }\end{array}$ & $\begin{array}{l}\text { none to slightly } \\
\text { perceptible } \\
\text { toasted smell }\end{array}$ & $\begin{array}{l}\text { slightly } \\
\text { sweet }\end{array}$ & $\begin{array}{l}\text { more } \mathrm{W} \\
\text { than } \mathrm{C}_{1}\end{array}$ \\
\hline 7 & $\begin{array}{l}\text { golden } \\
\text { brown }\end{array}$ & $\begin{array}{l}\text { creamy } \\
\text { white }\end{array}$ & $\begin{array}{c}\text { slightly } \\
\text { spongy \& } \\
\text { soft }\end{array}$ & $\begin{array}{c}\text { very small } \\
\text { aerated } \\
\text { pores/intact }\end{array}$ & $\begin{array}{c}\text { none to slightly } \\
\text { perceptible } \\
\text { toasted smell }\end{array}$ & $\begin{array}{l}\text { slightly } \\
\text { sweet }\end{array}$ & $\begin{array}{c}\text { well } \\
\text { blended } \\
\mathrm{C}_{1} \& \mathrm{~W}\end{array}$ \\
\hline 8 & $\begin{array}{l}\text { light } \\
\text { golden } \\
\text { brown }\end{array}$ & $\begin{array}{l}\text { creamy } \\
\text { white }\end{array}$ & $\begin{array}{c}\text { slightly } \\
\text { spongy \& } \\
\text { soft } \\
\end{array}$ & $\begin{array}{c}\text { slightly to } \\
\text { moderately } \\
\text { porous }\end{array}$ & $\begin{array}{c}\text { slightly } \\
\text { perceptible } \\
\text { toasted smell }\end{array}$ & $\begin{array}{l}\text { slightly } \\
\text { sweet }\end{array}$ & $\begin{array}{c}\text { more } \mathrm{C}_{1} \\
\text { than } \mathrm{W}\end{array}$ \\
\hline 9 & $\begin{array}{l}\text { golden } \\
\text { brown }\end{array}$ & $\begin{array}{c}\text { white to } \\
\text { creamy } \\
\text { white }\end{array}$ & $\begin{array}{c}\text { slightly } \\
\text { spongy \& } \\
\text { soft }\end{array}$ & $\begin{array}{c}\text { very small } \\
\text { aerated } \\
\text { pores/intact }\end{array}$ & $\begin{array}{c}\text { strongly } \\
\text { perceptible } \\
\text { toasted smell }\end{array}$ & $\begin{array}{c}\text { slightly to } \\
\text { moderately } \\
\text { sweet }\end{array}$ & $\begin{array}{c}\text { well } \\
\text { blended } \\
\mathrm{C}_{1} \& \mathrm{~W} \\
\end{array}$ \\
\hline 10 & $\begin{array}{l}\text { light } \\
\text { golden } \\
\text { brown }\end{array}$ & $\begin{array}{l}\text { creamy } \\
\text { white }\end{array}$ & $\begin{array}{c}\text { slightly } \\
\text { spongy \& } \\
\text { soft }\end{array}$ & $\begin{array}{l}\text { slightly } \\
\text { porous }\end{array}$ & $\begin{array}{c}\text { slightly to } \\
\text { moderately } \\
\text { perceptible } \\
\text { toasted smell }\end{array}$ & $\begin{array}{c}\text { slightly to } \\
\text { moderately } \\
\text { sweet }\end{array}$ & $\begin{array}{c}\text { well } \\
\text { blended } \\
\mathrm{C}_{1} \& \mathrm{~W}\end{array}$ \\
\hline 11 & $\begin{array}{l}\text { light } \\
\text { golden } \\
\text { brown }\end{array}$ & $\begin{array}{l}\text { creamy } \\
\text { white }\end{array}$ & slightly firm & $\begin{array}{c}\text { very small } \\
\text { aerated } \\
\text { pores/intact }\end{array}$ & $\begin{array}{c}\text { slightly } \\
\text { perceptible } \\
\text { toasted smell }\end{array}$ & $\begin{array}{c}\text { slightly to } \\
\text { moderately } \\
\text { sweet }\end{array}$ & $\begin{array}{c}\text { well } \\
\text { blended } \\
\mathrm{C}_{1} \& \mathrm{~W}\end{array}$ \\
\hline 12 & $\begin{array}{c}\text { dark } \\
\text { brown }\end{array}$ & $\begin{array}{l}\text { white to } \\
\text { pale white }\end{array}$ & $\begin{array}{c}\text { moderately } \\
\text { spongy } \\
\& \text { soft }\end{array}$ & $\begin{array}{c}\text { very small } \\
\text { aerated } \\
\text { pores/intact }\end{array}$ & $\begin{array}{c}\text { slightly to } \\
\text { moderately } \\
\text { perceptible } \\
\text { toasted smell }\end{array}$ & $\begin{array}{c}\text { moderately } \\
\text { sweet }\end{array}$ & $\begin{array}{c}\text { well } \\
\text { blended } \\
\mathrm{C}_{1} \& \mathrm{~W}\end{array}$ \\
\hline 13 & $\begin{array}{l}\text { light } \\
\text { golden } \\
\text { brown }\end{array}$ & $\begin{array}{l}\text { creamy } \\
\text { white }\end{array}$ & $\begin{array}{c}\text { moderately } \\
\text { spongy } \\
\& \text { soft }\end{array}$ & $\begin{array}{c}\text { very small } \\
\text { aerated } \\
\text { pores/intact }\end{array}$ & $\begin{array}{c}\text { slightly } \\
\text { perceptible } \\
\text { toasted smell }\end{array}$ & $\begin{array}{c}\text { slightly to } \\
\text { moderately } \\
\text { sweet }\end{array}$ & $\begin{array}{c}\text { well } \\
\text { blended } \\
\mathrm{C}_{1} \& \mathrm{~W}\end{array}$ \\
\hline 14 & $\begin{array}{l}\text { deep } \\
\text { golden } \\
\text { brown }\end{array}$ & $\begin{array}{l}\text { white to } \\
\text { pale white }\end{array}$ & $\begin{array}{c}\text { slightly } \\
\text { spongy \& } \\
\text { soft }\end{array}$ & $\begin{array}{c}\text { very small } \\
\text { aerated } \\
\text { pores/intact }\end{array}$ & $\begin{array}{c}\text { none to slightly } \\
\text { perceptible } \\
\text { toasted smell }\end{array}$ & $\begin{array}{l}\text { slightly } \\
\text { sweet }\end{array}$ & $\begin{array}{c}\text { well } \\
\text { blended } \\
\mathrm{C}_{1} \& \mathrm{~W}\end{array}$ \\
\hline 15 & $\begin{array}{l}\text { light to } \\
\text { golden } \\
\text { brown }\end{array}$ & white & $\begin{array}{c}\text { slightly } \\
\text { spongy \& } \\
\text { soft }\end{array}$ & $\begin{array}{c}\text { very small } \\
\text { aerated } \\
\text { pores/intact }\end{array}$ & $\begin{array}{c}\text { slightly } \\
\text { perceptible } \\
\text { toasted smell }\end{array}$ & $\begin{array}{l}\text { slightly } \\
\text { sweet }\end{array}$ & $\begin{array}{c}\text { well } \\
\text { blended } \\
\mathrm{C}_{1} \& \mathrm{~W}\end{array}$ \\
\hline
\end{tabular}

${ }^{1} \mathrm{~N}=14 \quad$ TRT-Treatment $\mathrm{G}$-Cassava $\mathrm{W}$ - Wheat 


\section{Crust Color}

The crust color of cassava-wheat bread was described by majority of the panelists (69\%) as "light golden brown" to "deep golden brown" (Table 4) with acceptability scores that ranged from 6.36 to 7.92 . It had an overall mean of 7.30 corresponding to "like moderately" in the 9-point Hedonic scale (Table 5). The analysis of variance of the response surface regression for crust color acceptability (Table 2) showed that a significant linear effect was found in the linear terms only of the equation. Parameter estimates (Table 3) showed a significant effect of the alpha-amylase, xylanase, and interaction of xylanase with the composite flour. Results revealed a direct relationship of the alpha-amylase level with the response and an inverse relationship of the level of xylanase with the response. This relationship means that the incorporation of higher level of alpha-amylase results in a higher acceptance of the crust color. On the other hand, the use of more xylanase results in an undesirable crust color. This is because crust color has a significant impact on bread attribute which influences consumer preference (Steffolani et al 2011). Xylanase has less contribution to the resulting crust color compared to that of alpha-amylase.

The presence of alpha-amylase degrades the damaged starch into small dextrins allowing the yeast to continuously work during dough fermentation, proofing, and the early stage of baking (Whitehurst \& Oort 2009). As the water content decreases in the crust, the temperature exceeds $100^{\circ} \mathrm{C}$ and this supports the occurrence of Maillard reaction (Vanin 2009). The action of this enzyme further produces glucose and maltose, thereby enhancing the Maillard reactions responsible for the browning of the crust (Whitehurst \& Oort 2009). This reaction involves the production of melanoidins as coloring components (Hadiyanto et al 2011).

A significant total regression model has been indicated in the result of the analysis of variance showing that the independent variables significantly affect the fit of the model for crust color acceptability. The contribution of each factor to the statistical fit of the model of the crust color acceptability response shows that the coefficients of both a-amylase and xylanase variables significantly contribute to the fit of the model predicting the crust color response of the product. Thus, results suggest that the determinants for the crust color acceptability of the product are a-amylase and xylanase levels.

\section{Crumb Color}

Crumb color acceptability of the product ranged from 7.07 to 7.79 with the bread containing the highest levels of cassava flour and xylanase having the lowest acceptability (Table 5). The overall mean falls on "like moderately" in the 9-point Hedonic scale with the value of 7.45. The quality description for color of the crumb was "pale white" to "creamy white" (Table 
4). The proper creamy white color of the crumb shows that dough oxidation during mixing has not been excessive (Calvel 2001). However, the presence of a-amylase and xylanase and a variation on the composition of flour used did not significantly affect the crumb color of the bread (Table 2).

\section{Crumb Texture}

The texture of cassava-wheat bread was described by the panelists as "slightly to moderately spongy and soft" (Table 4) with an overall response mean of 7.08 (Table 5) corresponding to "like moderately" in the 9-point Hedonic scale. The highest acceptability of crumb texture is attributed to the bread with the lowest level of composite flour, a-amylase, and xylanase.

Amylase helps the product retain original production freshness by primarily modifying the amylopectin portion of the wheat starch, which greatly reduces recrystallization over time, resulting in a softer product. Meanwhile, xylanase specifically modifies the arabinoxylan polysaccharides naturally present in the flour. This releases water that can be absorbed by gluten to produce stronger networks of gluten structure (Saral 2015).

Presented in Table 2 is the analysis of variance of the response surface for crumb texture. Results showed that xylanase had a quadratic negative effect on the texture response (Table 3). High levels of xylanase either in constant composite flour or a-amylase levels, result in a less acceptable crumb texture. This shows that higher dosage of xylanase could result to a less acceptable texture of the product and, must therefore, be used in proper dosage in combination with a-amylase and different levels of composite flour. Meanwhile, it is also the interaction of xylanase and composite flour level that influenced the acceptability of bread in terms of its texture.

The hydrolytic action of xylanase liberates the sugars, such as pentoses, which might be used by microbes for fermentation (Kumar 2016). Xylanase transforms water-insoluble hemicellulose into soluble form, which binds water in the dough, therefore decreasing dough firmness, increasing volume, and creating finer and more uniform crumbs (Panesar 2010). Though the composition of the flour used in this study has been modified with the addition of cassava flour, the impairment of its textural quality has been masked by the action of xylanase through increasing the elasticity of the gluten network, thereby decreasing the firmness of the crumb.

\section{Crumb Structure}

The structure of the crumb of cassava-wheat bread was described based on the presence of medium to large porous cells. Based on the results, the product was identified to have "very small aerated porous cells" to "slightly porous (medium to large holes) cells" (Table 4) with an acceptability range of 6.00 to 7.64 (Table 5). The lowest acceptability was of 
bread with the highest level of composite flour and a-amylase. The analysis of the overall response mean is almost "like moderately" (6.94) based on the 9-point Hedonic scale. This is likely to happen since the formulation contains a high percentage of cassava flour with no enzyme which could hinder the impairment of the quality of the bread. Cassava flour is composed mainly of starch and has non-gluten forming proteins which do not interfere with gluten development during dough mixing (Eduardo 2015). Cassava is deficient in protein content, particularly in Sulphur-containing amino acids (methionine and cysteine), with no ability to form a network that retains gas during dough development as wheat flour does (Montagnac et al 2009).

The crumb characteristic of fresh bread that has a great influence on consumer acceptance of the product is related to crumb moisture content after baking and amylose retrogradation (Eliasson \& Larsson 1993). The effect of the three variables on the crumb structure of the product is shown in Table 2. Results revealed that a-amylase had a quadratic negative effect on the crumb structure response of the product at $p \leq 0.05$ (Table 3 ), implying that every double unit of this factor causes a change in the acceptability of the response. Similarly, the interactions of two variables (xylanase and composite flour) influenced the crumb structure of the product and the result reflects a direct relationship to the crumb structure (Table 3).

The presence of a-amylase produced reducing sugars that promote a higher carbon dioxide production by yeast and, in consequence, the high gas pressure caused cell expansion. Smaller pentosans produced by xylanase are located around cell walls reinforcing them, thus avoiding gas loss (Gan et al 1995). This means that the combination of a-amylase and xylanase allowed for large dough expansion during proofing, without carbon dioxide loss, and highly aerated breads with large air cells and soft crumb (Steffolani et al 2011).

Highly significant effect was reflected on the total model of the response surface for variable crumb texture. This is an indication that the fit of the model for crumb structure acceptability is highly influenced by the independent variables. The coefficients of xylanase and composite flour influenced the fit of the model in predicting the crumb structure acceptability of the bread. High acceptability was observed at higher levels of a-amylase, while higher response surface of crumb structure was observed at low level combinations of composite flour and xylanase at constant a-amylase level.

\section{Aroma}

The observed overall response mean for aroma is "like moderately" on the 9-point Hedonic scale with a value of 7.25 (Table 5), while all treatments 
were perceived to have an aroma description of "slightly perceptible toasted smell" to "moderately perceptible toasted smell" (Table 4). The analysis of variance reflects that all treatments of cassava-wheat bread did not differ significantly, which means that none of the independent variables caused a change on the acceptability of aroma (Tables $2 \& 3$ ). None of the independent variables had significantly influenced the fit of the model for aroma acceptability.

\section{Taste}

The addition of sugar in the formulation has imparted the attribute of sweetness to the product. Thus, evaluation of the descriptive taste of the bread was based on the degree of sweetness. Results showed that the cassava-wheat bread taste ranged from "slight sweetness" to "moderate sweetness" (Table 4), having a response mean of 6.36 to 7.42 ("like slightly to like moderately") (Table 5). The treatment containing a high level of cassava flour without enzymes had the lowest acceptability, while the treatment with the highest level of cassava flour a-amylase $(0.0005 \% \mathrm{w} / \mathrm{w})$ and xylanase $(0.001 \% \mathrm{w} / \mathrm{w})$ had the highest acceptability. However, independent variables had no significant effect on the taste response of the product based on the analysis of variance using response surface (Tables 2 \&3).

\section{Flavor}

Treatments response mean ranged from 6.21 to 7.50 with an overall mean of 7.00 corresponding to "like moderately" on the 9-point Hedonic scale (Table 5). The lowest mean is attributed to the treatment with the highest content of cassava flour without any enzyme, while the highest mean was obtained by the treatment with the lowest level of cassava added with moderate levels of a-amylase and xylanase (Table 4).

Statistical analysis showed that a-amylase had a significant positive linear effect, while xylanase and composite flour had positive cross product effect on the flavor response (Tables $2 \& 3$ ). At higher a-amylase levels, high acceptance of the products can be obtained at any level of xylanase or composite flour.

The presence of a-amylase enhances the occurrence of Maillard reactions which aid in the development of an attractive baked flavor. The interaction of xylanase with composite flour is positive (higher level of cassava content) since this positive effect is more pronounced when bread is made with low protein flour. Poor gluten formation will be more difficult to handle when using a low protein flour source than when using a high protein flour. Offsetting the negative effect will, therefore, be more effective in low protein flour (Whitehurst 2009). 


\section{General Acceptability}

The overall acceptability represents a complex expression of liking the product as a whole. For cassava-wheat bread, it has an overall mean of 7.09 interpreted as "like moderately" on the 9-point Hedonic scale (Table 5). Treatment overall acceptance mean ranged from 6.29 to 7.57. Based on the statistical analysis, a-amylase had a linear positive effect, while xylanase had a quadratic negative effect on the general acceptability of the product. Direct relationship is demonstrated by the effect of a-amylase on the general acceptability response, while higher acceptability is portrayed when there is a low usage of xylanase even at a higher range of composite flour. Likewise, cross product effect was also found to be significant at $p \leq 0.05$ (Tables 2 \& 3). Results also showed a significant positive synergistic effect between a-amylase and xylanase.

\section{Cost Analysis}

Cost per treatment was calculated by summing up the price per unit of ingredients incurred in the formulation divided by the number of loaves produced in one formulation. The cost per loaf of cassava-wheat bread ranged from 40.25 to 41.47 pesos. The treatment with $15 \% \mathrm{w} / \mathrm{w}$ cassava flour and no enzyme had the lowest cost while the highest cost was incurred by the treatment with the highest addition of all independent variables in the formulation.

Figure 2 shows that the product cost is affected by the use of different levels of composite flour in the formulation. It is apparent that the cost increases with the increasing level of composite flour. This is because wheat and cassava flour comprises a large percentage of the product formulation.

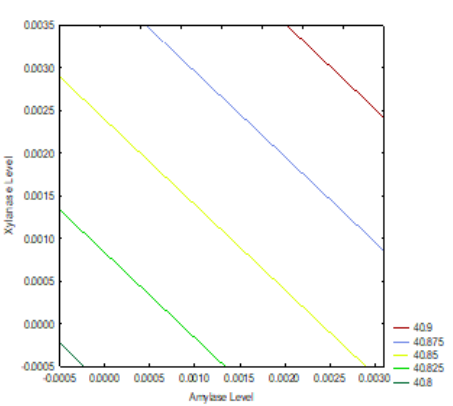

(a)

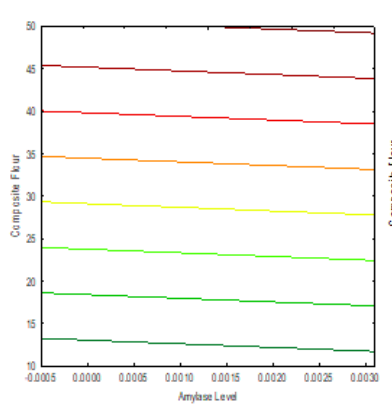

(b)

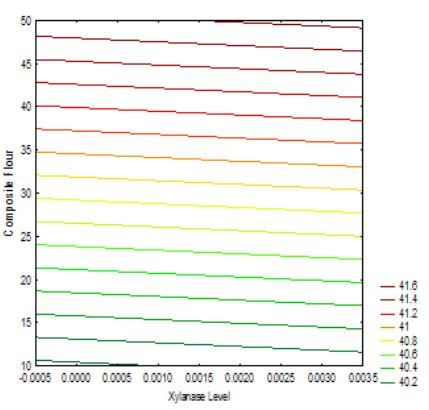

(c)

Figure 2. Response surface for the product cost of cassava-wheat bread at constant (a) $30 \% \mathrm{w} / \mathrm{w}$ composite flour, (b) $0.001 \% \mathrm{w} / \mathrm{w}$ xylanase, and (c) $0.001 \%$ w/wa-amylase level 


\section{Optimization Formulation for Sensory Acceptability of Cassava-Wheat Bread}

The optimum levels of the formulation were attained by considering all the contour plots produced from evaluating the different attributes of the product. Integrating the acceptance region for all the plots, considering a common acceptability rating of $\geq 7.20$ (like moderately) and cut-off value for cost of P41.00, generated superimposed plots (Figure 3 ). The common region, represented by the shaded portion, identifies the optimum condition in formulating cassava-wheat bread.

Set at an acceptability rating of $\geq 7.20$ (like moderately) and cut-off value for cost of P41.00, the optimum levels will be at a combination of a-amylase level from $0.00135 \%$ to $0.0023 \% \mathrm{w} / \mathrm{w}$ and xylanase from $0.00097 \%$ to $0.00175 \% \mathrm{w} / \mathrm{w}$ at constant $30 \% \mathrm{w} / \mathrm{w}$ composite flour (Figure 3a). The region was bounded within the acceptability of taste. At constant $0.001 \%$ xylanase, optimum will be at $0.00025 \%$ to $0.00273 \% \mathrm{w} / \mathrm{w}$ a-amylase and $10 \%$ to $39.5 \%$ $\mathrm{w} / \mathrm{w}$ composite flour (Figure $3 \mathrm{~b}$ ) and it is limited by the acceptability of crust color, crumb texture and structure, taste, flavor, and cost. At constant $0.001 \%$ a-amylase (Figure 3c), optimum will be at levels less than $0.00205 \%$ $\mathrm{w} / \mathrm{w}$ for xylanase and $10 \%$ to $39.5 \% \mathrm{w} / \mathrm{w}$ for composite flour, set between the boundaries of the cost, crust color, crumb texture, flavor, and taste acceptability. Analyzing these three separate superimposed graphs, the levels (\%w/w) for a-amylase, xylanase, and composite flour to be considered for optimum formulation are $0.0020,0.0012$, and 38 , respectively.

\section{Verification}

Verification test was further conducted to ensure the predictive ability of the model used to estimate the acceptability of responses in the optimum formulation. Predicted acceptability values of the optimum formulation were generated using the model equation presented in Table 6, and compared with the observed values obtained in the sensory evaluation using independent t-test (by groups) in STATISTICA.

Statistical analysis results revealed that all observed acceptability values, as shown in Table 7, for the different responses of the optimum product did not differ significantly from the predicted acceptability value based on the model equation. Results indicate the efficacy and consistency of the model in predicting the acceptability of the responses. This further signifies that the chosen levels for the different independent variables as the optimum formulation were correct and met the criteria set at the acceptability rating of $\geq 7.20$ on the 9 -point Hedonic scale. 
Veril \& Amestoso

(a)

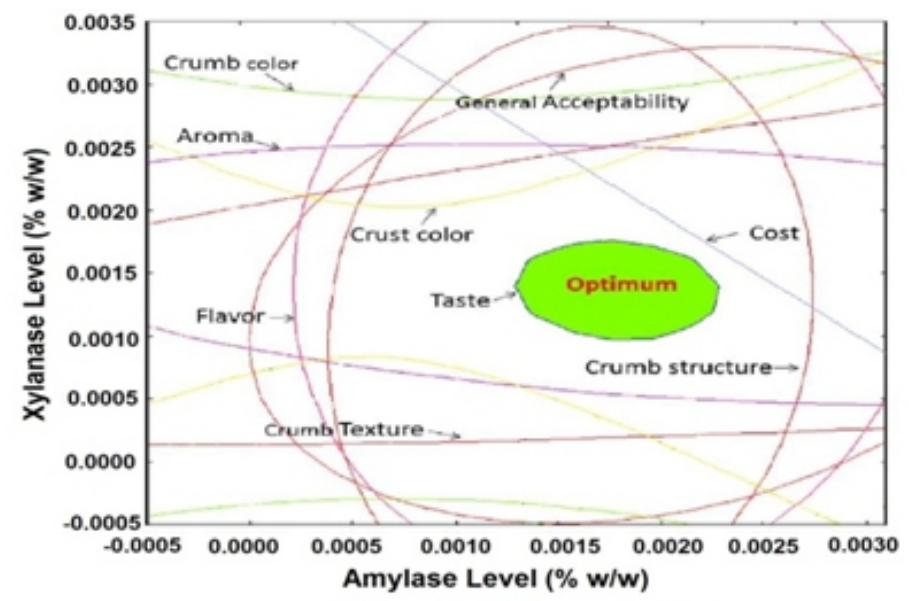

(b)

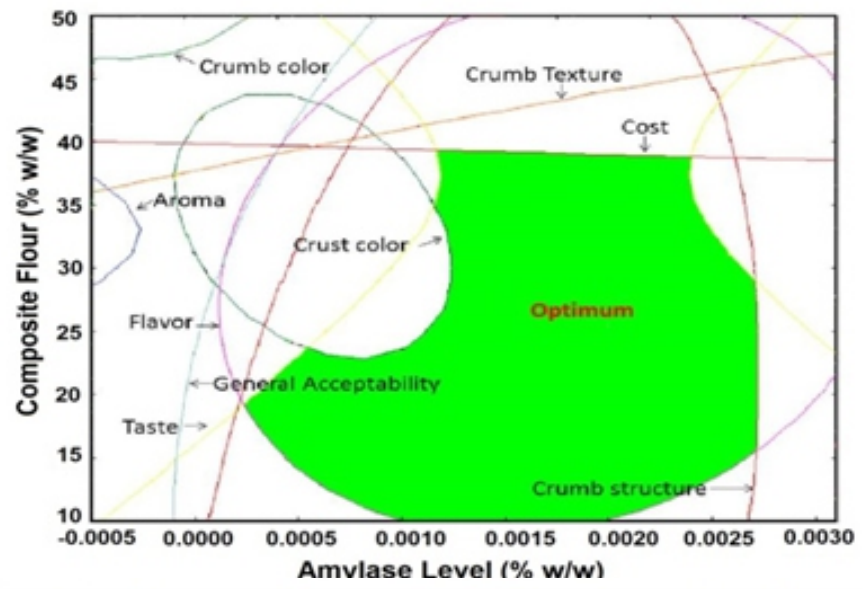

(c)

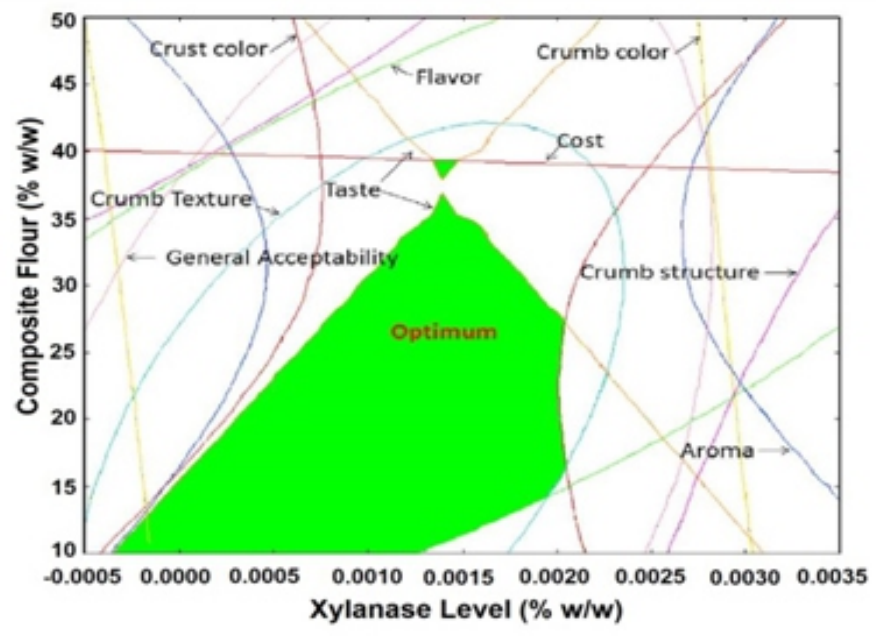

Figure 3. Optimum region of cassava-wheat bread set at acceptability rating of $\geq 7.20$ in the 9-point Hedonic scale and cost of P41.00 at constant (a) $30 \% \mathrm{w} / \mathrm{w}$ composite flour, (b) $0.001 \% \mathrm{w} / \mathrm{w}$ xylanase, (c) $0.001 \% \mathrm{w} / \mathrm{w}$ a-amylase level 
Table 6. Model equation and predicted values for the acceptability of the sensory attributes for cassava-wheat bread

\begin{tabular}{|c|c|c|}
\hline Parameters & Model Equation & $\begin{array}{l}\text { Predicted } \\
\text { Value } \\
\text { (optimum) }\end{array}$ \\
\hline Crust Color & $\begin{aligned}= & 7.384690+0.506886^{\star} x- \\
& 0.143372^{\star} y+0.082143^{\star} z+0.452785^{*} x^{\star} x- \\
& 0.111001^{\star} x^{\star} y- \\
& 0.809867^{\star} y^{\star} y+0.189286^{\star} x^{\star} z+0.425000^{\star} y^{\star} z \\
& +0.185566^{\star} z^{\star} z\end{aligned}$ & 7.44 \\
\hline Crumb Color & $\begin{aligned}= & 7.585935+0.154669^{\star} x- \\
& 0.176376^{\star} y+0.062143^{\star} z+0.191866^{\star} x^{\star} x- \\
& 0.037106^{\star} x^{\star} y-0.581870^{\star} y^{\star} y+0.29787^{\star} x^{\star} z- \\
& 0.092143^{\star} y^{\star} z+0.003665^{\star} z^{\star} z\end{aligned}$ & 7.61 \\
\hline Crumb Texture & $\begin{aligned}= & 7.469528+0.158551^{\star} x-0.197184^{\star} y- \\
& 0.219286^{\star} z-0.023667^{\star} x^{\star} x+0.235402^{\star} x^{\star} y- \\
& 0.786218^{\star} y^{\star} y-0.134286^{\star} x^{\star} z+0.513571^{\star} y^{\star} z- \\
& 0.316900^{\star} z^{\star} z\end{aligned}$ & 7.34 \\
\hline Crumb Structure & $\begin{aligned}= & 7.65447+0.15126 * x-0.18319 * y-0.26429 * z- \\
& 1.35350^{\star} x^{\star} x+0.12607^{\star} x^{\star} y- \\
& 0.342377^{*} y^{*} y+0.27143^{\star} x^{\star} z+0.63571^{*} y^{\star} z- \\
& 0.10769^{\star} z^{\star} z\end{aligned}$ & 7.54 \\
\hline Aroma & $\begin{aligned}= & 7.388709+0.049399^{\star} x+0.041656^{\star} y- \\
& 0.131429^{\star} z-0.056520^{\star} x^{\star} x-0.116155^{\star} x^{\star} y- \\
& 0.656753^{\star} y^{\star} y+0.022143^{\star} x^{\star} z- \\
& 0.087143^{*} y^{\star} z+0.384488^{\star} z^{\star} z\end{aligned}$ & 7.39 \\
\hline Taste & $\begin{aligned}= & 7.266270+0.178156^{\star} x-0.115117^{\star} y- \\
& 0.300000^{\star} z-0.481839^{\star} x^{\star} x-0.113380^{*} x^{\star} y- \\
& 0.767221^{*} y^{\star} y- \\
& 0.014286^{*} x^{\star} z+0.028571^{*} y^{\star} z+0.304849^{\star} z^{\star} z\end{aligned}$ & 7.20 \\
\hline Flavor & $\begin{aligned}= & 7.742439+0.319582^{\star} x+0.010593^{\star} y+0.06071 \\
& 4^{\star} z-0.965844^{\star} x^{\star} x+0.079445^{\star} x^{\star} y- \\
& 0.367938^{\star} y^{\star} y+0.239286^{\star} x^{\star} z+0.646429{ }^{*} y^{\star} z- \\
& 0.555466^{\star} z^{\star} z\end{aligned}$ & 7.66 \\
\hline $\begin{array}{l}\text { General } \\
\text { Acceptability }\end{array}$ & $\begin{aligned}= & 7.725603+0.450988^{\star} x-0.198023^{\star} y- \\
& 0.181429^{\star} z-0.695034^{\star} x^{\star} x+0.336255^{\star} x^{\star} y- \\
& 0.745111^{\star} y^{\star} y+0.186429^{\star} x^{\star} z+0.334286^{*} y^{\star} z- \\
& 0.160195^{\star} z^{\star} z\end{aligned}$ & 7.63 \\
\hline
\end{tabular}

Optimum formulation: $\mathrm{x}=0.002 \% \mathrm{w} / \mathrm{w}$ a-amylase, $\mathrm{y}=0.0012 \% \mathrm{w} / \mathrm{w}$ xylanase, $\mathrm{z}=38 \% \mathrm{w} / \mathrm{w}$ composite flour

\section{CONCLUSION}

Incorporation of a-amylase and xylanase in the production of bread from composite flour (cassava and wheat) greatly improved the bread quality as it attained an overall acceptability mean of as high as 7.10 which is "like moderately" on the 9-point Hedonic scale. The presence of a-amylase had a 
significant effect on the crust color, crumb structure, flavor, and general acceptability, while xylanase affected only the crust color, crumb texture, and general acceptability of the cassava-wheat bread. The interaction of xylanase and composite flour had a positive significant effect on the crust color, crumb texture and structure, flavor, and general acceptability. Moreover, the synergistic effect of a-amylase and xylanase positively influenced the overall acceptance of the product, indicating the improvement of the quality of bread containing cassava flour. The product cost containing these enzymes ranged from PhP 40.25 to PhP41.47 per $420.8 \mathrm{~g}$ to $446.7 \mathrm{~g}$ of loaf which is comparable to the PhP42.00 to PhP45.00 of loaf in the market.

Cassava flour could be acceptable for incorporation in the production of bread to as high as $39.5 \%$ with the addition of less than $0.00205 \%$ of xylanase and $0.00135 \%$ to $0.00273 \%$ of a-amylase level with minimum impairment on the quality of bread due to high content of cassava flour. Verified optimum formulation of $38 \% \mathrm{w} / \mathrm{w}$ cassava flour, $0.002 \% \mathrm{w} / \mathrm{w}$ aamylase, and $0.0012 \% \mathrm{w} / \mathrm{w}$ xylanase will result in a product whose quality is comparable to that of the commercial $100 \%$ wheat bread preferred by children and adult consumers.

\section{REFERENCES}

Baillet E, Downey G \&Tuohy M. 2003. Improvement of Texture and Volume in white bread rolls by incorporation of microbial hemicellulose preparations. Recent Advances in enzymes in Grain Processing. Proceedings from the $3^{\text {rd }}$ European Symposium on Enzymes in Grain Processing, Katholieke Universities Leuven, Belgium. pp. 255-259.

Bankole YO, Tanimola AO, Odunukan RO \& Samuel DO. 2013. Functional and Nutritional Characteristics of Cassava Flour (Lafun) Fortified with Soybeans. Journal of Educational and Social Research 3 (8):163-170.

Butt MS, Nadeem MT, Ahmad Z \& Sultan MT. 2006. Xylanase and their Applications in Baking Industry Review. Food Technology Biotechnology 46(1):22-31.

Calvel R and Wirtz R. 2001.The Taste of Bread: A Translation. Springer Science and Business Media.

Eduardo M. 2015. Enhancing Composite Cassava Bread Quality: Effect of Cassava Pre-Treatment and Baking Improvers (PhD Dissertation). Chalmers University of Technology, Gothenburg. Sweden.

Eliasson A and Larsson K. 1993. Bread In: Cereals in Breadmaking. United States of America. Eriksson E. 2013. Flour from three local varieties of Cassava (Manihote sculenta Crantz): Physico-chemical Properties, Bread Making Quality and Sensory Evaluation. Publikation/Sveriges Lantbruksuniversitet, Institutionen För Livsmedelsvetenskap (371):1- 
41.Gan Z, Ellis PR \& Schofield JD. 1995. Mini Review: Gas Cell stabilization and Gas retention in Wheat Bread Dough. Journal of Cereal Science 21:215-230.

Hadiyanto $S$ and Boxtel AJ. 2011. Parameter estimation in bread baking model. Reaktor 13(4):201-210.

Miguel AM, Meyer TM, Figueiredo EV, Lobo BP \& Dellamora-Ortiz GM. 2013. Enzymes in Bakery:Current and Future Trends (pp287-321). Intech Open Science Mind.

Montagnac JA, Davis CR \& Tanumihardjo SA. 2009. Nutritional value of cassava for use as a staple food and recent advances for improvement. Comprehensive Reviews in Food Science and Food Safety 8 (3):181-194.

Saral D 2015. Judging the Freshness of Bread. DuPont Industrial Sciences, Netherlands. Retrieved on October 5, 2016 from http://www.foodquality andsafety.com/article /judging-the-freshness-of-bread2/?singlepage $=1$ \&theme $=$ print-friendly

Steffolani ME, Ribotta PD, Perez GT \& Leon AE. 2011. Combination of glucose oxidase, a-amylase and xylanase affect dough properties and bread quality. International Journal of Food Science and Technology 47:525-534.

Vanin F, Lucas T \& Trystram G. 2009. Crust formation and its role during baking. Trends in Food Science and Technology, Elsevier 20 (8):333-343.

Whitehurst RJ and Oort MV. 2009. Enzymes in Food Technology $\left(2^{\text {nd }} \mathrm{edn}\right)$. Wiley-Blackwell Publishing, John Wiley and Sons, West Sussex, United Kingdom. 